\title{
Pyla-Vigla: A Case Study Assessing the Imperial Strategies of the Hellenistic Diadochoi in Cyprus
}

\author{
Brandon R. Olson, R. Scott Moore, Thomas Landvatter, \\ JuSTIN STEPHENS
}

\begin{abstract}
The aim of the present study is to examine the mechanisms the Diadochoi implemented to gain and maintain control over Cyprus using Pyla-Vigla, a recently discovered fortified garrison, as a case study. Alexander the Great's successors faced a seemingly insurmountable problem: How does one govern, control, and maintain the largest territorial empire the world had ever seen? Alexander's imperial strategy was predicated upon maintaining native governing institutions of newly subjugated lands and appointing new leaders. This system could not work for the Diadochoi because without a clear path to succession, a twenty-nine-year period of incessant conflict ensued throughout the Eastern Mediterranean. The surviving successors adopted various strategies to exercise imperial authority over their rivals, which ultimately led to the creation of three ruling Hellenistic dynasties: Ptolemies, Seleucids, and Antigonids. Pyla-Vigla represents one of many such strategies.
\end{abstract}

Keywords: Pyla-Vigla, Antigonus, Ptolemy, Diadochoi, Hellenistic Cyprus, imperialism, Pyla-Koutsopetria

Brandon R. Olson, Metropolitan State University of Denver, Denver, Colorado; bolson18@msudenver.edu; (D) 0000-0003-3069-8406

R. Scott Moore, Indiana University of Pennsylvania, Indiana, Pennsylvania; rsmoore@iup.edu; (D) 0000-0003-0320-7464

Thomas Landvatter, Reed College, Portland, Oregon; landvatt@reed.edu; (D) 0000-0002-6075-810X Justin Stephens, Metropolitan State University of Denver, Denver, Colorado; jsteph46@msudenver.edu; (D) 0000-0001-8985-1052

The emergence of the Hellenistic era following the death of Alexander the Great in 323 BC cast a great shadow of uncertainty throughout the Eastern Mediterranean. Alexander, the quintessential autonomous leader, did little to share his imperial authority, yet he surrounded himself with strong, spirited individuals that proved integral to the success of his campaigns. 
Alexander's imperial policies following the subjugation of any given area was simple, as he often mimicked the political structure of the former geopolitical entity. Those regions previously subject to the Achaemenid Persian Empire continued a system of satrapies, where Alexander replaced local satraps with an ally. The eastern provinces, especially around the Indus River Valley, maintained a kingdom-oriented organisation with a monarch of Alexander's choosing. While one can argue as to the degree to which Alexander actually created a centralised empire after the conclusion of his campaigns in $326 \mathrm{BC}$ and death three years later, it is clear that continuation of such an entity required an active, charismatic, militarily astute and singular leader. This proved to be impossible for reasons of timing. Alexander died without a clear path to successorship as his only son was an infant and his two surviving half-brothers Arrhidaeus and Herakles were problematic. Furthermore, Alexander's realm was in its infancy and, as is the case for all empires, required regular interventions against local uprisings and reassertions of authority to maintain control. It was at this juncture that the successors devised a minimum of three separate plans in $323 \mathrm{BC}, 320 \mathrm{BC}$, and $311 \mathrm{BC}$ to move forward. All three documented partitions named a king (or soon to be king), a regent, and divided the realm into satrapies or regions governed by a successor or ally. ${ }^{1}$ The plans paved the way for either Alexander's son (Alexander IV) or his half-brother Arrhidaeus (Philip III) to become the sole legitimate heir of Alexander the Great and provide the long-term answer to dynastic succession and stability. These plans, however, never materialised. The assassinations of Philip III (Alexander's half-brother) in 317 BC, Olympias (Alexander's mother) in 316 BC, and Roxane (Alexander's wife) and Alexander IV (Alexander's son) in 310 BC ended the Argead Dynasty and any hopes of a singular ruler taking over Alexander's great empire.

Following these assassinations, there were no less than twenty individuals with legitimate claims to at least part of the empire. The nearly thirty years following Alexander's death were some of the most turbulent in the ancient world. By 294 BC, three successors - Ptolemies, Seleucids, and Antigonids - had carved out their own disparate imperial spheres from Alexander's realm. Moving beyond the assassinations, alliances, and power grabs characterising this period, one must also consider the imperial machinations of the successors. Alexander's system of using a highly skilled, technologically advanced army to take over a region and then, from a centralised position maintain the status quo, was not an option moving forward. The Ptolemies, Seleucids, and Antigonids, devised unique methods to take over an area and maintain control of it. The fortified site of Pyla-Vigla (Vigla) in south-east Cyprus reflects one of the many disparate methods the Diadochoi deployed to achieve their greater imperial aspirations. Either Ptolemy or Antigonus constructed and garrisoned small, yet heavily fortified, forts situated in strategic locations to exercise imperial dominion over a previous semi-autonomous island and protect those interests against others.

\footnotetext{
1 See the Partition of Babylon (323 BC), Partition of Triparadisus (320 BC), and the Agreement of 311 BC.
} 


\section{THE SITE OF PYLA-VIGLA}

The site of Vigla was discovered by the Pyla-Koutsopetria Archaeological Project (PKAP), a landscape oriented archaeological project ongoing since 2003 (Figs 1-3). ${ }^{2}$ The site sits atop a natural plateau overlooking the Mediterranean and with an in-filled embayment to the south and Cyprus' interior to the north. The site is also situated along the primary terrestrial route connecting Salamis and Kition, the two major urban entities in the region. Five years of intensive pedestrian survey yielded remnants of significant fortifications and a settlement dated to the Hellenistic period based on the presence of a ceramic assemblage of this era. Alongside the main PKAP survey project, small-scale excavations were conducted at Vigla in 2008, 2009, and 2012, with the specific goal of the ground-truthing of survey results and refining the site's chronology. Larger excavation seasons followed in 2018 and 2019, the beginning of a long-term, multi-year excavation project to further investigate Vigla's occupation, fortification system, and stratigraphy. ${ }^{3}$ The vast majority of the layers excavated at Vigla that produced cultural material presented a high level

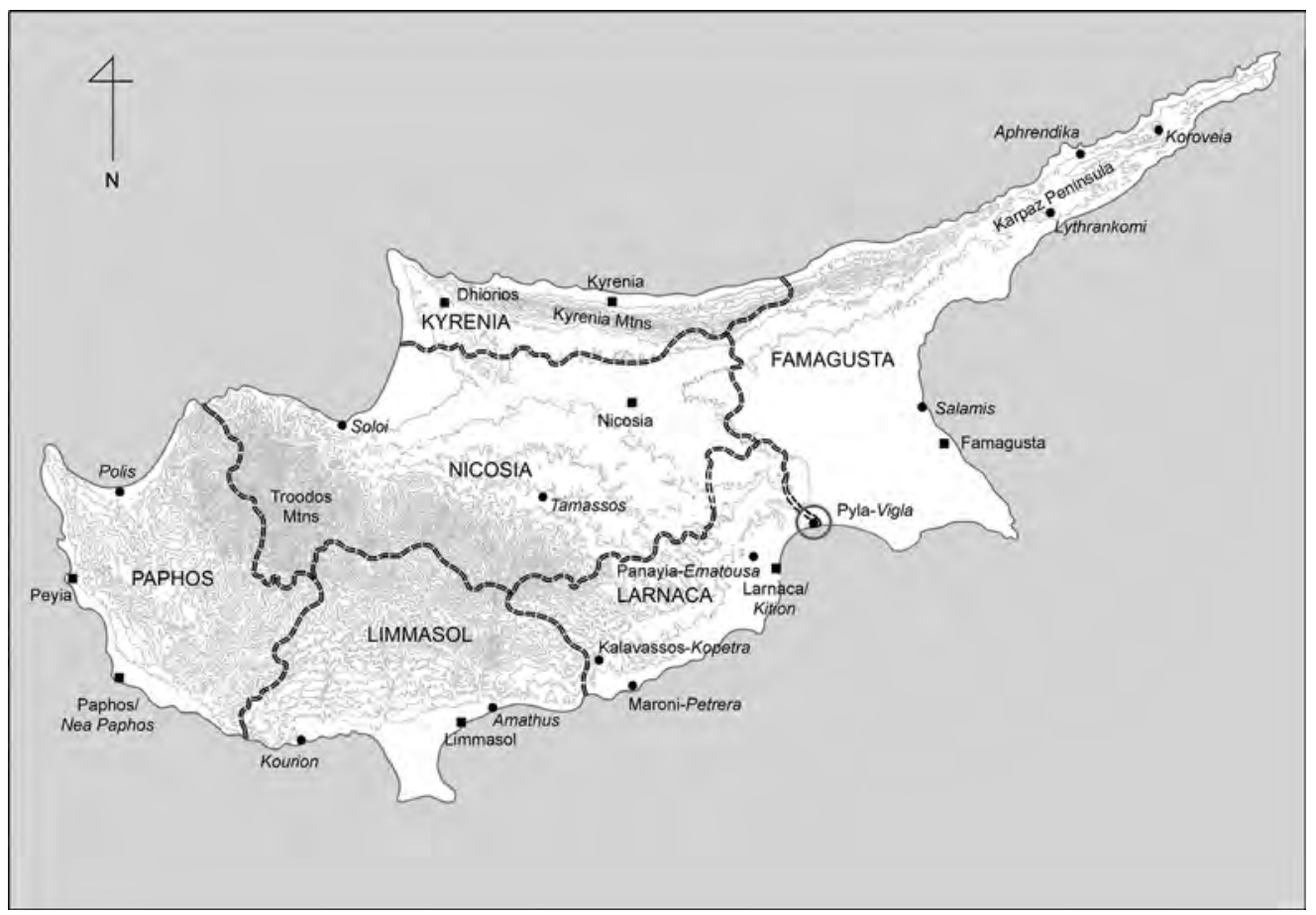

1. A map showing the principle urban entities of ancient Cyprus (Drawing: B.R. Olson; (C) Pyla-Koutsopetria Archaeological Project).

2 See: Caraher, Moore, Pettegrew 2008; 2014; Caraher et al. 2005; 2007; 2017; Olson et al. 2013.

3 See: Landvatter et al. 2018; Stephens et al. 2019. 


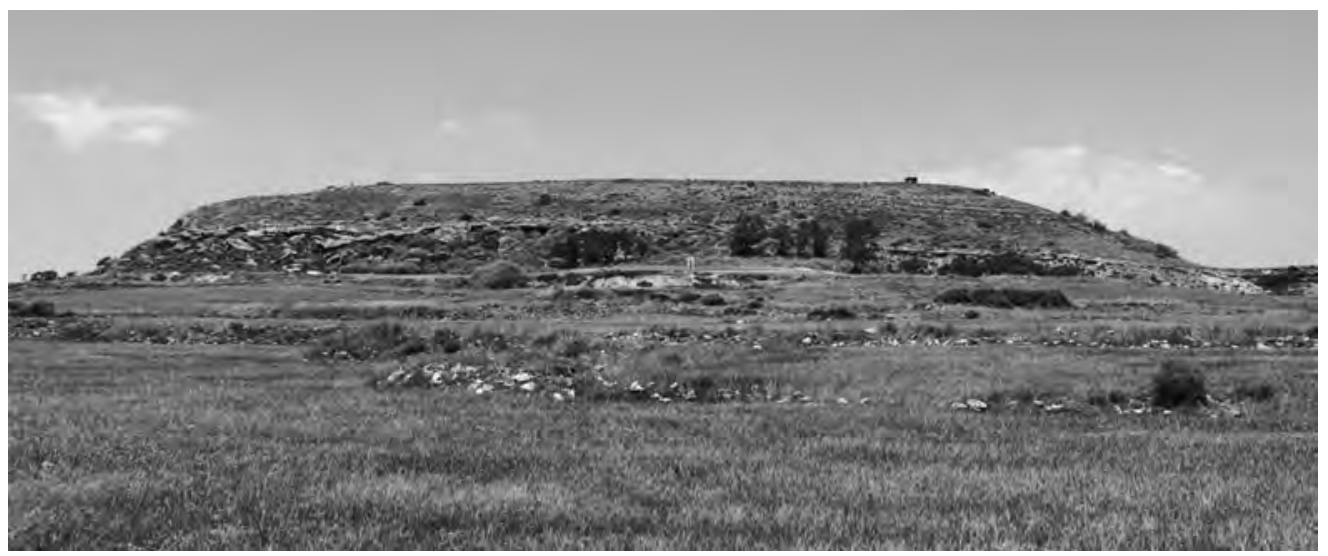

2. An image of the Vigla plateau from the plain looking north (Phot. B.R. Olson; @ Pyla-Koutsopetria Archaeological Project).

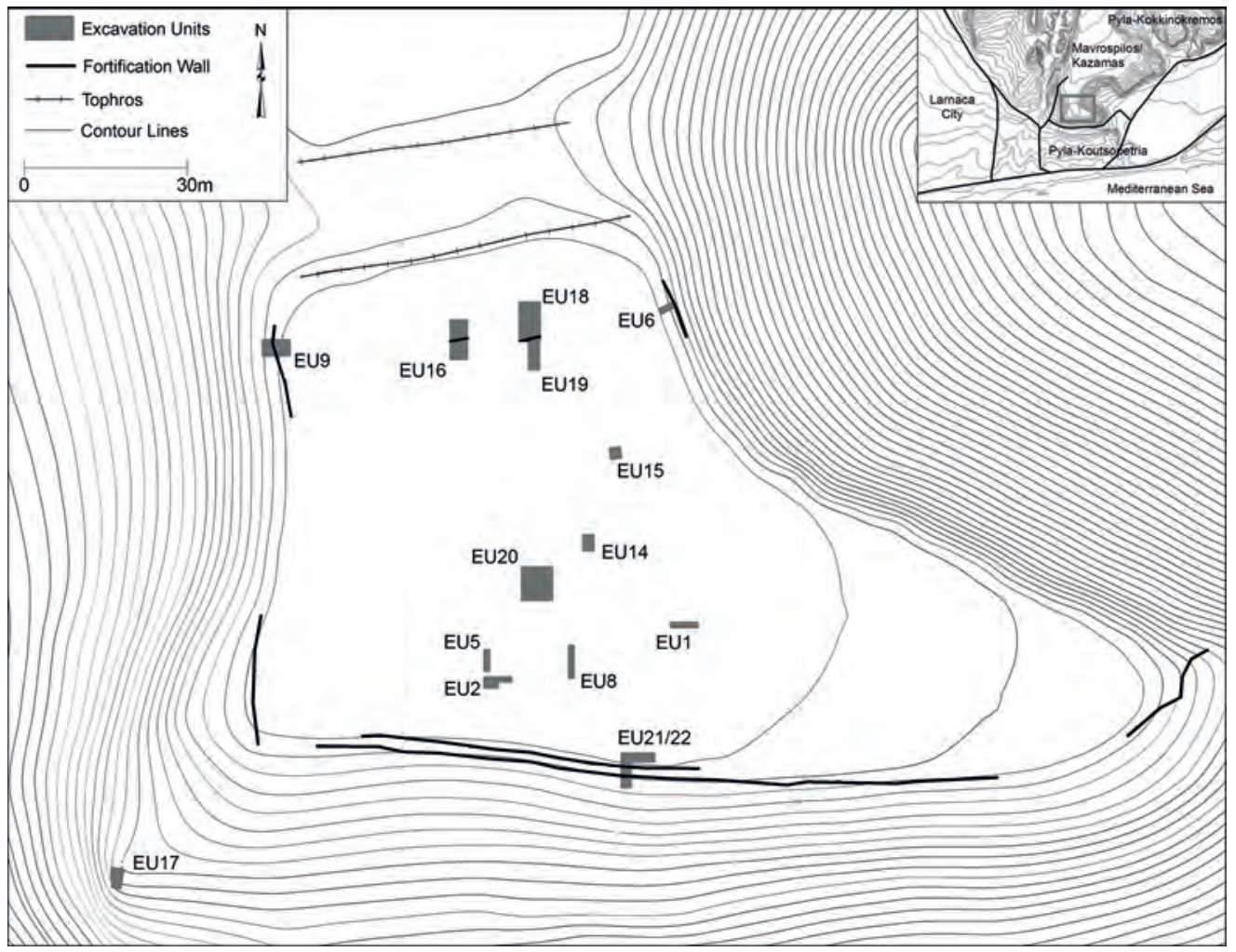

3. A top plan of the Vigla plateau showing the locations of all trenches excavated by PKAP (Drawing: B.R. Olson; (C) Pyla-Koutsopetria Archaeological Project). 
of stratigraphic integrity, as they were sealed on the top by mudbrick tumble and on the bottom by bedrock. Also absent were later intrusions into the stratified layers that are common throughout archaeological sites in the Eastern Mediterranean.

\section{ARCHITECTURE}

Excavations on the plateau within the fortification wall have revealed two primary phases of occupation, both dating to the early Hellenistic period. In the domestic contexts excavated thus far, there were two distinct floor levels, each corresponding to a different period of occupation. The earliest phase of occupation typically included manipulating the bedrock surface where necessary to construct a number of stone socles with roughly hewn field stones upon which a mudbrick superstructure and presumably a thatched roof were built (Fig. 4a). The interior spaces were leveled with fill and a combination of compacted earth and gypsum flooring provided an occupational surface. A second phase was identified in most of the soundings and was represented by a new series of packed earth and gypsum floors (Fig. 4b-c). In some cases, the interior walls were manipulated to create a new architectural footprint within existing structures but the overall architectural plan of the
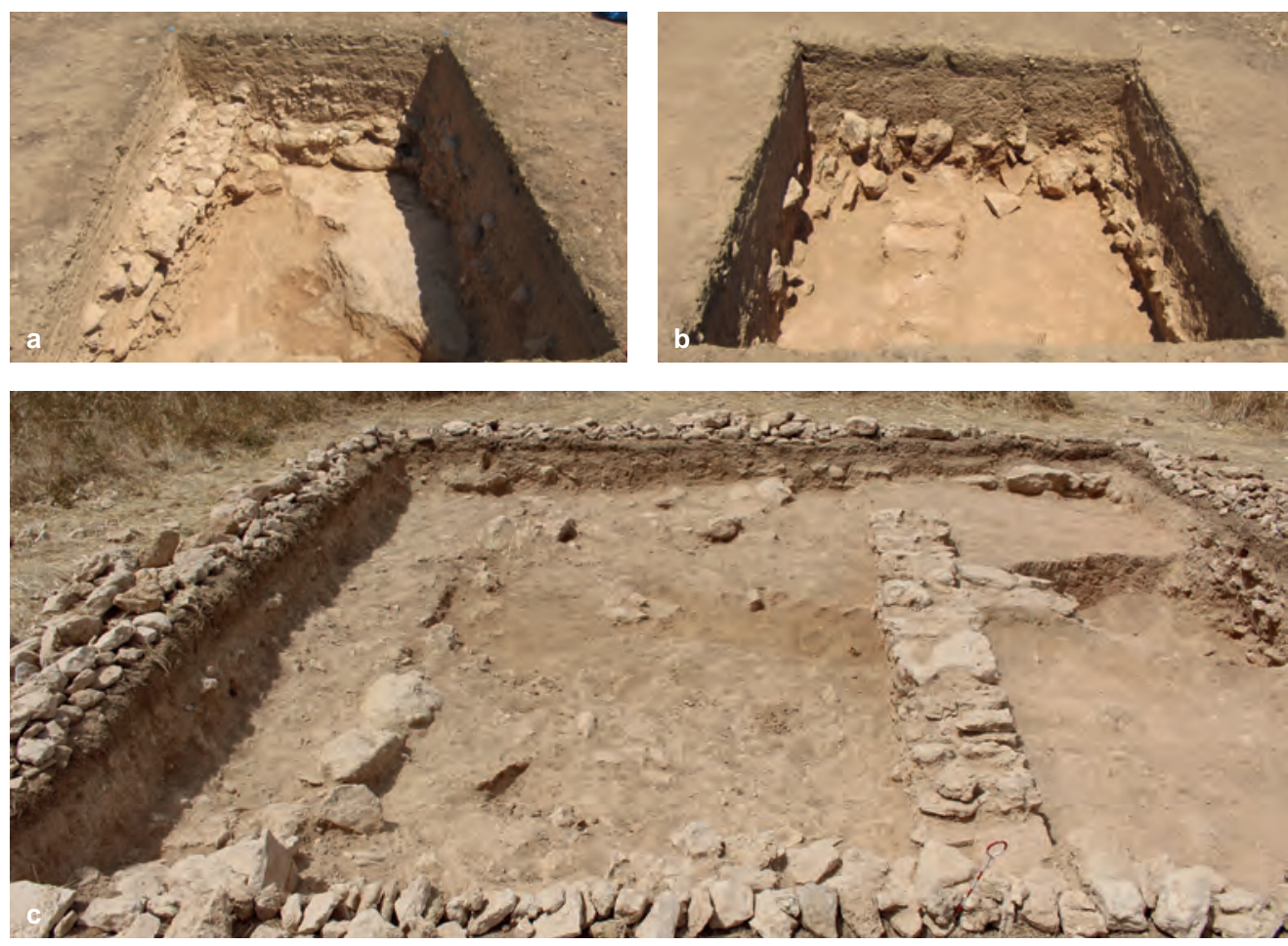

4. A representative collection of domestic architecture exposed at Vigla (Phot. B.R. Olson; ㄷ Pyla-Koutsopetria Archaeological Project). 


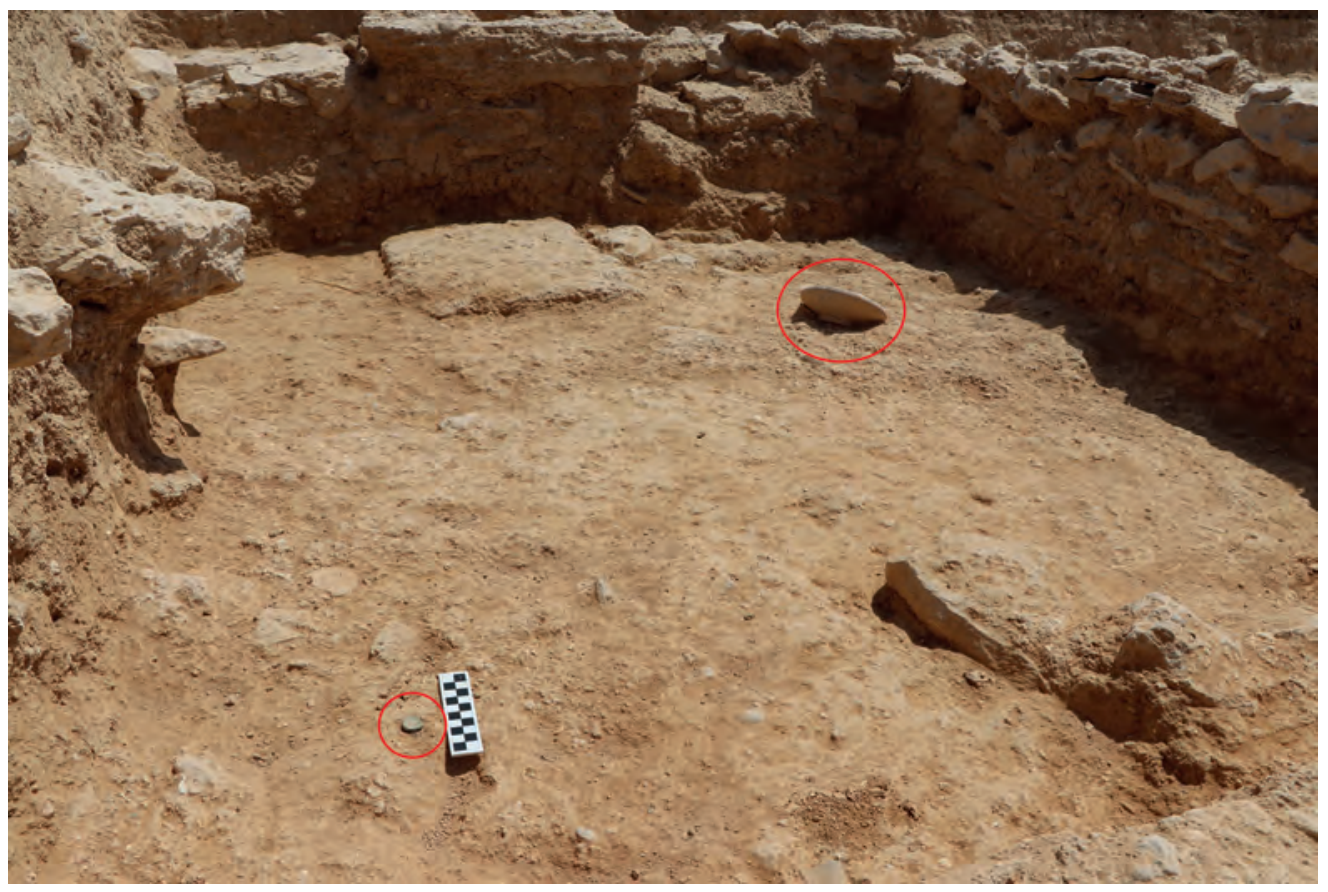

5. A packed earth floor with an in situ echinus bowl and coin (Phot. B.R. Olson; (C Pyla-Koutsopetria Archaeological Project).

site appears to have changed little between the two phases. Excavators discovered significant quantities of complete vessels and other artifacts (coins, weapons, etc.) on the floor surfaces of the second phase accompanied by a thick layer of mudbrick collapse (Fig. 5), leading one to believe that the site occupants either abandoned it in a hurry or purposefully destroyed it prior to abandonment. Furthermore, the material remains found in the earliest cultural layer, the first phase's floor fill, and the latest cultural layer, the mudbrick collapse above the second phase's floor, are chronologically indistinguishable. The same ceramic forms, weapons, and coin issues were found throughout the stratigraphy, demonstrating two important characteristics. First, the plateau had little if any occupation before or after the early Hellenistic period. Second, occupation on the plateau was relatively short lived.

\section{FORTIFICATIONS}

The fortification system at Vigla consists of three primary features: advantageous natural topography, a rock cut fosse on the north side of the site, and a perimeter wall encompassing various construction materials and methods. The Vigla plateau measures approximately 1.60 ha with a maximum elevation of $58.5 \mathrm{~m}$. The landform is a natural formation with steep slopes on the eastern, western, and southern sides making it easily defendable from these cardinal directions. The fortification wall at Vigla itself encompasses an area 


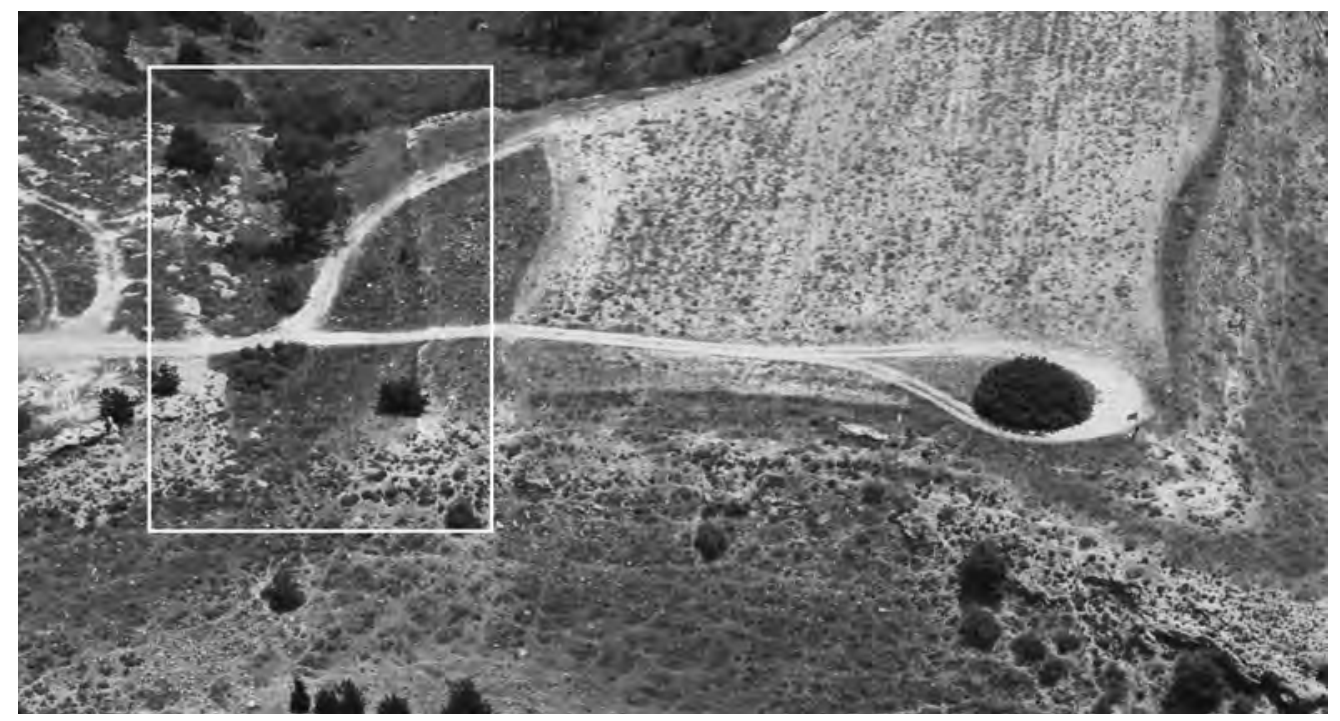

6. An aerial photo looking east of the Vigla plateau showing the rock cut fosse (Phot. B.R. Olson; (C) Pyla-Koutsopetria Archaeological Project).

of approximately 1.25ha. On the western, southern, and eastern sides of the plateau, the wall follows the natural contour of the slope. Scant traces of the wall are preserved on the surface with the longest exposed section occurring along the southern slope. Despite the poor state of preservation, the wall was recorded for over $100 \mathrm{~m}$ and in numerous places both faces of the wall allowed a width calculation of $1.7-1.8 \mathrm{~m}$.

The north side of the site is protected by a fosse cut into the natural bedrock and a fortification wall built atop bedrock (Figs 6-7). The northern extent of the wall is nearly invisible on the surface, but it appears to have followed a slight ridge along the northern part of the plateau. Excavations by looters in early 2010 exposed a small section of the wall's coursed southern face. Further to the west, more sections of the wall are visible, but these appear to follow a different trajectory from the section exposed by the looters, suggesting that the wall changes course at some point near the north-western corner. Excavations in 2012 exposed a section of the northern fortification wall (Fig. 7a). The wall was built using roughly cut field stones $20-30 \mathrm{~cm}$ in diameter for the northern and southern faces, while the interior was filled with rubble. The wall measures $2.8 \mathrm{~m}$ in width and, based on the height of the wall and limited quantities of stone present, likely had a mudbrick superstructure. In 2018 excavations approximately 10-15m to the east of the 2012 sounding exposed another section of the fortification wall (Fig. 7b). This extent appeared different than the remains excavated in 2012. Located immediately beneath the first layer of mudbrick collapse, an eleven-course in situ mudbrick superstructure was discovered. The mudbrick wall completely enveloped the uneven first course of the lowest extent of the wall, which included four courses of large, cut stone blocks. Although it was impossible to determine the extent of any given block since their terminal ends ran into the eastern 

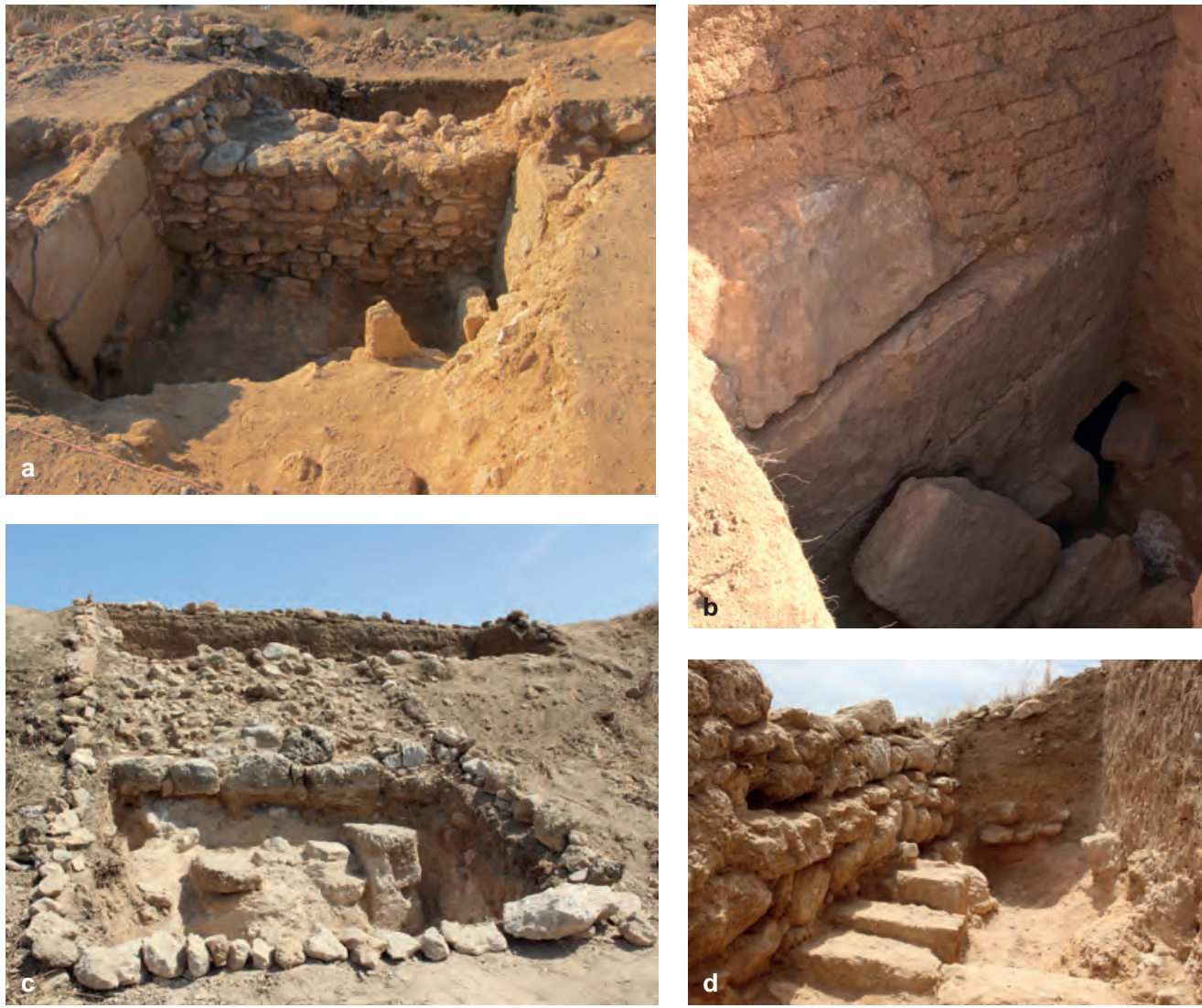

7. A representative collection of fortification wall sections exposed at Vigla: a. north central fortification wall exposure from EU16; b. ashlar and mudbrick section of fortification wall from EU18; c. south central fortification wall exposure from EU21/22; d. ashlar feature discovered on the northern side of southern fortification wall from EU21/22 (Phot. B.R. Olson; (C) Pyla-Koutsopetria Archaeological Project).

and western balks, there were at least five individual blocks ranging from $46 \mathrm{~cm}$ to $52 \mathrm{~cm}$ thick. At the base of the wall, there was a small chamber purposefully built into the lowest courses. Farther north, there is an 18-20m fosse cut into the local bedrock. This imposing feature likely combined the practical advantage of local quarrying to procure materials for the fortification wall with the tactical advantage of providing defenders additional height from which to defend against hostile forces approaching from the north. ${ }^{4}$

Excavations undertaken in 2019 focused on exposing a representative section of the southern fortification wall to compare it to the size and construction style of the sections found elsewhere. The southern edge of the wall was visible prior to excavations and the full width and northern face were found directly beneath a thin layer of overburden. The wall itself is an unevenly founded wall of rough-hewn fieldstones that extends in an east-west

${ }^{4}$ Hadjicosti et al. forthcoming. 
direction with a maximum height of six courses (Fig. 7c-d). The size and construction methods of this feature (i.e. fieldstone walls and rubble core) are similar to those discovered in 2012 along the northern edge of the plateau. The wall was founded in the west on a pre-existing ashlar feature. It is constructed with a single course of cut ashlars arranged in a linear fashion and set immediately atop bedrock.

The western side of the fortification system is the least visible on Vigla as it is most likely covered with soil eroded from the summit. In 2009, a section of the fortification wall was excavated. The section of wall exposed also appeared to be yet another different style of construction. The northern side was built using considerable quantities of the white gypsum mortar to contain a substantial rubble core faced with heavily mortared blocks. It has been argued that this represents the remains of a tower designed to protect an entrance at the north-western corner. ${ }^{5}$ Farther to the south, the wall appears on the surface and continues for approximately $20 \mathrm{~m}$.

The eastern side of the Vigla plateau is the most treacherous, as eroding bedrock and steep slopes posed significant threats to archaeological activities. One sounding was opened along the north-east section of the wall. The exposed wall revealed a mud-brick superstructure and a substantial perimeter wall built parallel of rough field stones. This perimeter wall was $1.7 \mathrm{~m}$ in width and built with two faces of larger, roughly-dressed stones and a rubble fill.

In sum, the fortification system encircling the Vigla plateau consists of a substantial $1.5-2.8 \mathrm{~m}$ thick fortification wall constructed atop bedrock. The construction style of the fortification wall mirrors the typical pattern of domestic structures found in the interior: socles constructed on top of bedrock, which was accompanied with a mudbrick superstructure. The fieldstone structure of rubble core is unique to the fortification system and made logistical sense given its monumental width. There are deviations in this pattern where larger cut blocks were used in the north/north-east section and mortar in the north-west corner, which potentially represent an entrance and tower respectively. In addition to the significant investment of a large, well-constructed encircling fortification wall, the builders of Vigla also constructed the fosse in the north to further bolster the defendable capabilities of the site along its most vulnerable area.

\section{WEAPONS}

The presence of metal weapons in bronze, lead, and iron at Vigla further substantiates its military character. Excavations have yielded a number of iron knives (Fig. 8a), spearheads, and spits. Particularly common weapons are bronze projectiles including tanged catapult bolts (Fig. 8b) and arrowheads (Fig. 8c) and socketed arrowheads of the Scythian variety (Fig. 8d). ${ }^{6}$ The most prevalent weapon type found at Vigla are lead sling-bullets and evidence

\footnotetext{
${ }^{5}$ Hadjicosti et al. forthcoming.

${ }^{6}$ For Scythian type socketed arrowheads in Cyprus, see: Olson, Najbjerg 2017; Olson, Najbjerg, Moore 2018.
} 


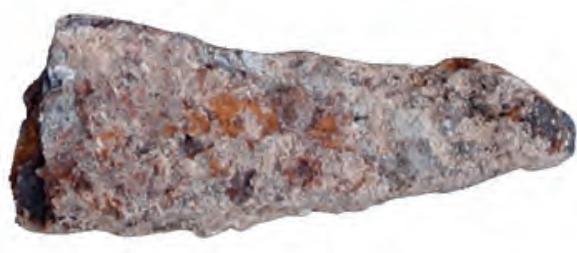

a

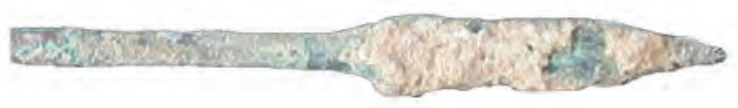

b

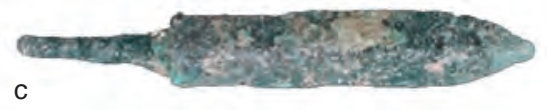

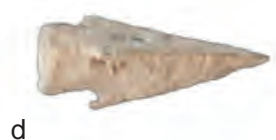

d

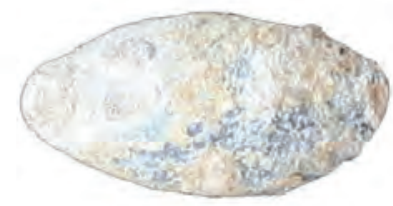

e

8. A typical assemblage of weapon types found at Vigla: a. iron knife fragment; b. bronze tanged catapult bolt; c. bronze tanged arrowhead; d. bronze socketed arrowhead of the Scythian type; e. lead sling bullet (glans) (Phot. B.R. Olson; (C) Pyla-Koutsopetria Archaeological Project).

of their manufacture (Fig. 7e). ${ }^{7}$ Excavations yielded a dozen sling-bullets, one of which

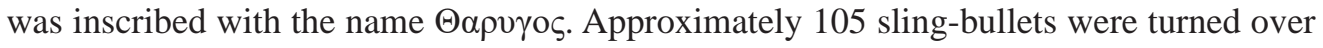
to the Cyprus Museum that were looted from Vigla in the late 1970s. Of the 105 bullets recovered, 32 bear inscriptions while four others depict symbols. ${ }^{8}$ Of the 36 inscribed

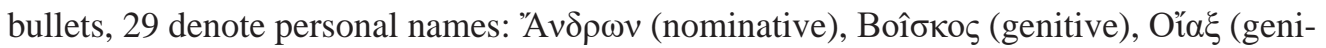

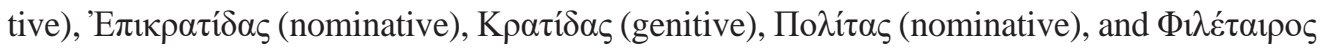
(genitive), while four preserve one of two symbols, and three glandes preserve fragmentary inscriptions or unidentified abbreviations. ${ }^{9}$ The ubiquity and diversity of these finds demonstrate that Vigla was occupied by soldiers and craftsmen skilled in the production of weapons.

\section{NUMismatics}

To date, the PKAP numismatic corpus from Vigla is from the last half of the fourth to early third centuries BC (Table 1, Fig. 9). Of the 16 coins excavated by PKAP at Vigla during preliminary excavations, two are illegible, 11 are an issue of Alexander, either during his life or soon after, and three are Evagoras II issues. The Alexander issue depicted an obverse showing a right-facing beardless head of Herakles, and a reverse with a club and bow and quiver/bow case flanking a legend reading $\mathrm{A} \Lambda \mathrm{E} \Xi \mathrm{AN} \triangle \mathrm{POY}$. The Evagoras II issue dates

\footnotetext{
7 Olson 2014.

${ }^{8}$ See: Olson 2014; Nicolaou 1977; 1979; 1980; Kantirea, Summa (Eds) 2020: 90-95.

9 Fraser, Matthews 1987; Preisigke 1967; Foraboschi 1971.
} 
Table 1. Inventory of all coins discovered by PKAP at Vigla

\begin{tabular}{|c|c|c|c|}
\hline Inv. No. & Obverse & Reverse & Issue \\
\hline 5013_1003 & Beardless head of Herakles, r. & $\begin{array}{l}\text { Bow in bow case and club; } \\
\text { inscr. A } \Lambda E \Xi A N \triangle P O Y\end{array}$ & Alexander \\
\hline 5013_1004 & Beardless head of Herakles, r. & $\begin{array}{l}\text { Bow in bow case and club; } \\
\text { inscr. A } \Lambda E \Xi A N \triangle P O Y\end{array}$ & Alexander \\
\hline 5013_50 & Beardless head of Herakles, r. & $\begin{array}{l}\text { Bow in bow case and club; } \\
\text { inscr. A } \Lambda E \Xi A N \triangle P O Y\end{array}$ & Alexander \\
\hline 5106_1001 & Beardless head of Herakles, r. & $\begin{array}{l}\text { Bow in bow case and club; } \\
\text { inscr. A } \Lambda E \Xi A N \triangle P O Y\end{array}$ & Alexander \\
\hline 5309_1003 & Beardless head of Herakles, r. & $\begin{array}{l}\text { Bow in bow case and club; } \\
\text { inscr. A } \Lambda E \Xi A N \Delta \text { POY }\end{array}$ & Alexander \\
\hline 5314.1002 .1 & Beardless head of Herakles, r. & $\begin{array}{l}\text { Bow in bow case and club; } \\
\text { inscr. A } \Lambda E \Xi A N \triangle P O Y\end{array}$ & Alexander \\
\hline 5317.1 & Beardless head of Herakles, r. & $\begin{array}{l}\text { Bow in bow case and club; } \\
\text { inscr. A } \Lambda E \Xi A N \triangle P O Y\end{array}$ & Alexander \\
\hline 5521.1001 .1 & Beardless head of Herakles, r. & $\begin{array}{l}\text { Bow in bow case and club; } \\
\text { inscr. A } \Lambda \text { E } \Xi A N \Delta P O Y\end{array}$ & Alexander \\
\hline 5523.1 & Beardless head of Herakles, r. & $\begin{array}{l}\text { Bow in bow case and club; } \\
\text { inscr. A } \Lambda E \Xi A N \triangle P O Y\end{array}$ & Alexander \\
\hline 8060_1002 & Beardless head of Herakles, r. & $\begin{array}{l}\text { Bow in bow case and club; } \\
\text { inscr. A } \Lambda E \Xi A N \triangle P O Y\end{array}$ & Alexander \\
\hline 8079_1001 & Beardless head of Herakles, r. & $\begin{array}{l}\text { Bow in bow case and club; } \\
\text { inscr. A } \Lambda E \Xi A N \triangle P O Y\end{array}$ & Alexander \\
\hline 5013_1006 & Head of Athena, 1. & Illegible & Evagoras II \\
\hline 8057_1001 & Head of Athena, 1. & Illegible & Evagoras II \\
\hline 8077_1001 & Head of Athena, l. & Illegible & Evagoras II \\
\hline 5108_1001 & Illegible & Illegible & Illegible \\
\hline 8103_1001 & Illegible & illegible & Illegible \\
\hline
\end{tabular}

to the middle of the fourth century $\mathrm{BC}$ and depicts the head of Athena facing left on the obverse. The reverses on all are difficult to interpret and require further study, but they likely depict either the forepart of a bull, facing left or the prow of a ship. Many of these coins are quite worn, but the main aspects of the iconography are present. Mint marks are not readily seen, but either Kition or Salamis, as the nearest major city-kingdoms, makes the most sense as the mint of origin.

While the numismatic evidence requires further study, the overwhelming consistency in the PKAP finds from Vigla is telling. The primary occupation and abandonment of Vigla clearly has a terminus post quem of Alexander's reign, beginning in 332 BC: one coin 

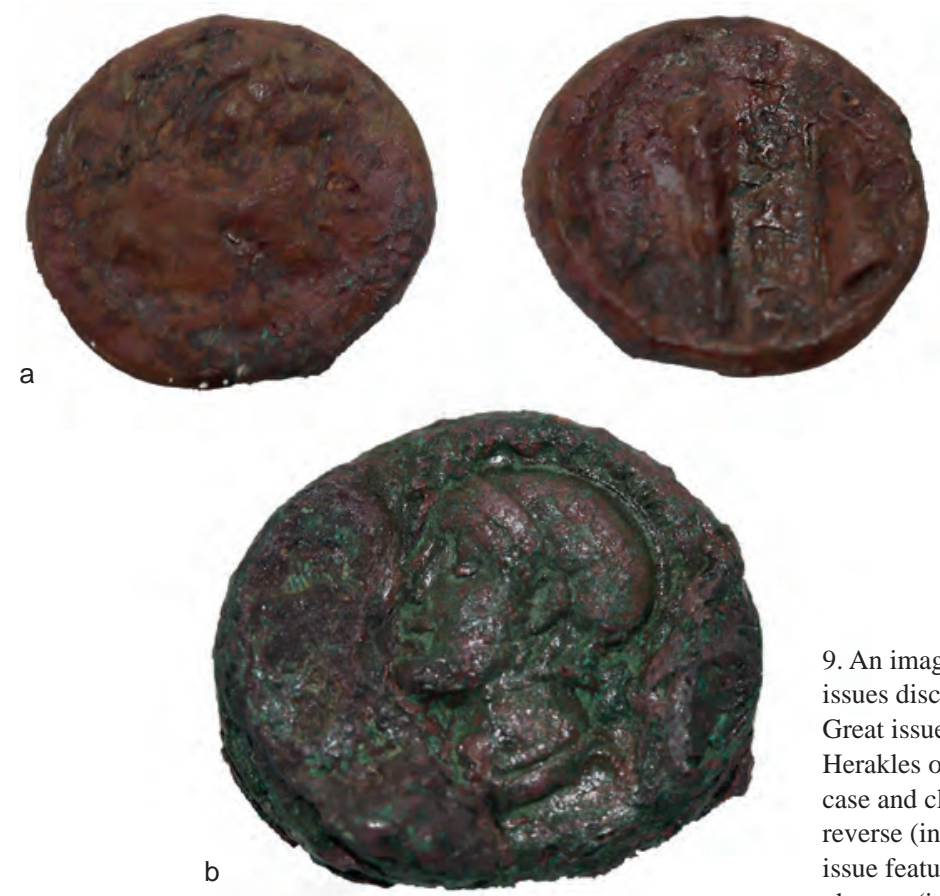

9. An image showing the only two coin issues discovered at Vigla: a. Alexander the Great issue featuring a beardless head of Herakles on the obverse and a bow in bow case and club; inscr. A $\Lambda$ E $\Xi \mathrm{AN} \triangle \mathrm{POY}$ on the reverse (inv. no. 5013_50); b. Evagoras II issue featuring the head of Athena on the obverse (inv. no. 5013_1006)

(Phot. B.R. Olson; (C) Pyla-Koutsopetria Archaeological Project).

(8060_1002, an Alexander issue) was found lying flat on a floor, near an intact echinus bowl. Given the ubiquity of the Alexander Herakles issues during his life and soon after, at present it is difficult to say more than this in terms of dating. The presence of Evagoras II issues that predate Alexander by some decades indicates perhaps a link with more distant Salamis, rather than Kition. It is interesting that, as of yet, PKAP has not excavated any coins at Vigla that date after the Alexander issues.

\section{CERAMICS}

The ceramic finds from Vigla have proved to be particularly significant. ${ }^{10}$ Excavations on the plateau revealed extensive pottery deposits lying in situ on floor surfaces and features such as a slab-lined pit set against the north fortification wall with one of the most complete assemblages of early Hellenistic pottery yet discovered on Cyprus. The ceramic corpus is currently under study but there is no evidence of chronological differentiation between Vigla's earliest and latest Hellenistic phases. Analysis of this assemblage is ongoing, but the range of vessels included (fine wares, cooking wares, transport vessels, and utility

\footnotetext{
${ }^{10}$ Moore, Olson 2014.
} 

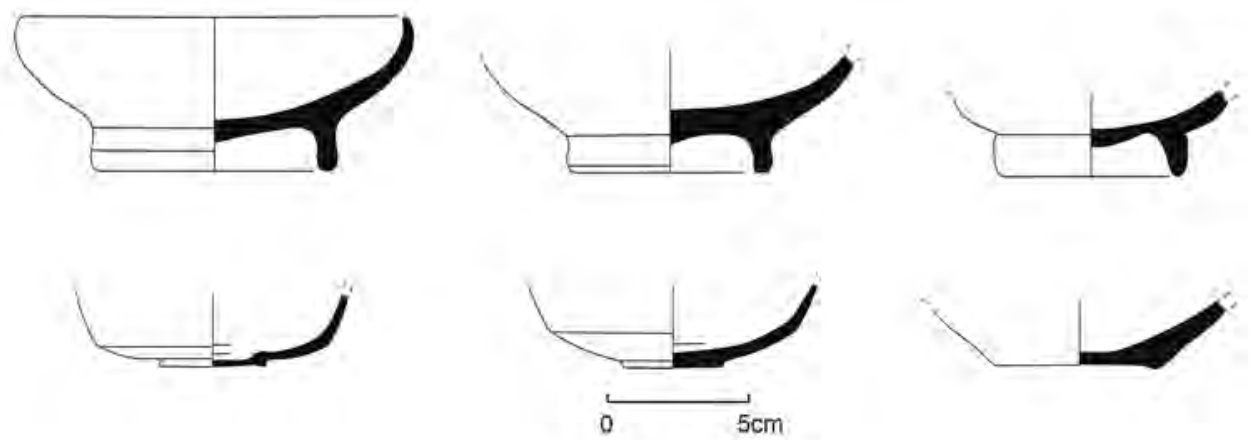

10. An assemblage of single-serving bowls from Vigla (Drawing: B.R. Olson; @ Pyla-Koutsopetria Archaeological Project).

vessels) are distinct. The excavation of several floor surfaces, sub-floor fill, and discrete features has yielded a representative ceramic assemblage of Vigla's inhabitants that above all was dominated by small single-serving portion bowls with various rim configurations (Fig. 10). The shape is the most common throughout the site and was produced in different wares and at different local and foreign workshops. This pattern is similar to a roughly contemporary corpus excavated at Jebel Khalid and is indicative of the dining habits of soldiers within a fortified space. ${ }^{11}$

\section{THE IMPERIAL STRATEGIES OF THE DIADOCHOI IN CYPRUS}

Ascribing archaeological remains to specific historical events or personages is an often difficult task without epigraphic evidence substantiating one's claims. This is especially the case in a historically ambiguous period like the Hellenistic era. Therefore, situating Pyla-Vigla's position within the turmoil of the Diadochoi struggles in the closing years of the fourth and opening years of the third centuries BC requires a careful assessment of the historical and archaeological records. In the two centuries prior to the Hellenistic era, Cyprus was defined by a series of disparate independent political units and diverse cultural identities. By 350 BC, Cyprus' cultural and political landscape was markedly heterogeneous, with notable influences from Greek, Near Eastern, and Egyptian culture. ${ }^{12}$ Cyprus was politically organised into a number of city-kingdoms that while nominally independent were in fact ruled under the imperial authority of the Achaemenid Persian Empire. Following Alexander the Great's decisive victory over Darius III in 333 BC at the Battle of Issus, most of the Cypriot kings saw an opportunity and began turning against the Persians. The Cypriot dissent against Persia culminated a year later when numerous city-kingdoms

\footnotetext{
11 Clarke et al. 2002.

12 Gordon 2012; Papantoniou 2012; Keen 2012.
} 
Table 2. Late Cypro-Classical through early Hellenistic timeline

\begin{tabular}{|l|l|}
\hline \multicolumn{1}{|c|}{ Date } & \multicolumn{1}{c|}{ Historical event } \\
\hline 332 вC & Many Cypriot kings offer aid to Alexander the Great in besieging Tyre. \\
\hline 323 вC & Alexander the Great dies in Babylon. \\
\hline $321-316$ BC & $\begin{array}{l}\text { Ptolemy allies himself with four Cypriot kings (Nikokles/Paphos, Androkles/Amathus, Pasikrates/ } \\
\text { Soloi, and Nikokreon/Salamis), while Antigonus secures alliances with the kings of Kition, Kyrenia, } \\
\text { Lapithos, and Marion. }\end{array}$ \\
\hline $316-312$ BC & $\begin{array}{l}\text { Antigonus invades Babylon and Seleucus flees to Cyprus and allies himself with Ptolemy. With } \\
\text { Seleucus, his brother Menelaus, and aid from the aforementioned Cypriot king allies, Ptolemaic } \\
\text { forces attack Antigonus' Cypriot allies and take control of the whole island. }\end{array}$ \\
\hline $312-310$ BC & $\begin{array}{l}\text { Ptolemy appoints Nikokreon strategos and gives him control of Salamis and the former Antigonid } \\
\text { friendly kingdoms but he dies in 310 BC. Ptolemy then appoints his brother Menelaus to the same } \\
\text { position, who begins minting his own coins in Salamis. Ptolemy eliminates autonomous rule in Cyprus. }\end{array}$ \\
\hline 306 BC & $\begin{array}{l}\text { Battle of Salamis between Ptolemy and Antigonus. Antigonus secures the victory and regains } \\
\text { control of Cyprus. }\end{array}$ \\
\hline 301 BC & $\begin{array}{l}\text { Antigonus dies and Demetrius' authority begins to fade in the Eastern Mediterranean without his father. } \\
\text { Ptolemy reconquers Cyprus and the island remains in Ptolemaic control until the middle of the } \\
\text { first century BC. }\end{array}$ \\
\hline
\end{tabular}

aided Alexander in his naval siege of Tyre in 332 BC (see Table 2)..$^{13}$ The political system centred on independent city kingdoms, however, did not last far past Alexander's death in 323 BC. Cyprus, along with the rest of the remnants of Alexander's empire, was caught in the struggle between his many successors. Cyprus in particular was a point of contention between Ptolemy and Antigonus whereby Cypriot kings chose to either support one of the Diadochoi or remain neutral. The choosing of sides or the decision not to select any and the shifting of positions followed by the results of various conflicts threw the city-kingdom system into disarray and led to further fragmentation. By 312 BC, Ptolemy had conquered much of the island and ended Cypriot kingship, killing the king of Kition, arresting others, and appointing Nikokreon, the king of Salamis, as strategos of the island. Despite some degree of success for the Antigonid following Demetrius Poliorcetes defeat of Ptolemy I at the Battle of Salamis in 306 BC and subsequent control of the island, Antigonid's control began to fade at the turn of the century. ${ }^{14}$ The Ptolemies and Antigonids continued to skirmish until $294 \mathrm{BC}$, when the Ptolemies gained permanent control of the island, ruling over it until $58 \mathrm{BC}$.

For the purpose of examining the imperial strategies of the Diadochoi and establishing the chronology of Vigla, the fortification system and coinage are the two classes of material culture that are the most informative. Both classes are inherently datable using a comparative approach and both are characteristic, in this case, of an invading army's prerogatives and

\footnotetext{
${ }^{13}$ Arrian 2.20-22; Plutarch, Alexander 29.2.

14 Diod. 19.56-57.
} 
timing respectively. Claire Balandier, in a series of studies, argues that the fortification of Cyprus' civic spheres and their hinterlands between the Archaic and Hellenistic eras took place in two discrete periods of hyper-fortification during the sixth and third centuries BC. ${ }^{15}$ During the sixth century city wall systems were either built, expanded, or restored several civic spaces across the island, including those of Salamis and Kition. The rationale for this first period of intensive fortification, according to Balandier, was likely a result of Achaemenid Persian pressure. Following Onesilos' revolt and the Persian reaction, of the ubiquitous sixth-century newly built fortifications, only the city walls of Amathus and Salamis remained standing into the beginning of the fifth century. By the second half of the fourth and first part of the third centuries, Balandier identifies a wholly new defensive strategy on Cyprus, one that shifts attention away from the civic space and also incorporates smaller settlements, citadels, forts, and watchtowers. The new defensive outlook, she argues, is a product of the Antigonids after their victory over the Ptolemies at Salamis in 306 BC, as she ascribes the fortification of Palaeokastro (north of Paphos), the new harbour and city walls at Amathus, and the new harbour at Nea Paphos to them. The Ptolemaic view of Cyprus as a mere springboard to Cilicia and Syria precluded any significant investment in the fortification of the island. The Antigonids, on the other hand, saw Cyprus, according to Balandier, as an imperial holding in need of protection. ${ }^{16}$

During the period of semi-autonomous rule prior to Alexander, there were eight active mints in Cyprus with most city-kingdoms minting their own coins under their own authority: Marion, Soloi, Lapithos, Paphos, Kourion, Amathus, Kition, and Salamis. ${ }^{17}$ Following, Alexander's conquest in 332 BC, all eight of these mints remained in operation but coins became standardized in iconography and weight, bringing them in line with other issues in Alexander's realm. ${ }^{18}$ Following Alexander's death in $323 \mathrm{BC}$ and the initial period of political instability that followed until $312 \mathrm{BC}$, Cypriot mints resumed coining in the name of their own city-kings. It is also clear that coins continued to be minted in the name of Alexander and using the same iconography for some time after his death. ${ }^{19}$ In the two cities closest to Vigla, Kition and Salamis, Alexander issues were minted until 320 BC in the former and perhaps until $300 \mathrm{BC}$ in the latter. ${ }^{20}$

After 294 BC, coin issues were produced with standard Ptolemaic iconography, but prior to these issues were more varied, with Ptolemaic issues from 312-306 BC, and Antigonid issues from 306-295 BC. The numismatic situation for the end of the fourth and beginning of the third century BC is thus complex, with an admixture of local Cypriot coinage, Alexander issues, and those of the Antigonids, and Ptolemies circulating throughout Cyprus. In this period, Salamis, as the administrative centre throughout the second half of the fourth

\footnotetext{
15 Balandier 2002; 2007; 2011a; 2011b.

16 Balandier 2011a.

17 Destrooper-Georgiades 2007: 267-269.

18 Destrooper-Georgiades 2007: 269-270.

19 Destrooper-Georgiades 2007: 271-272.

20 Destrooper-Georgiades 2007: n. 32.
} 


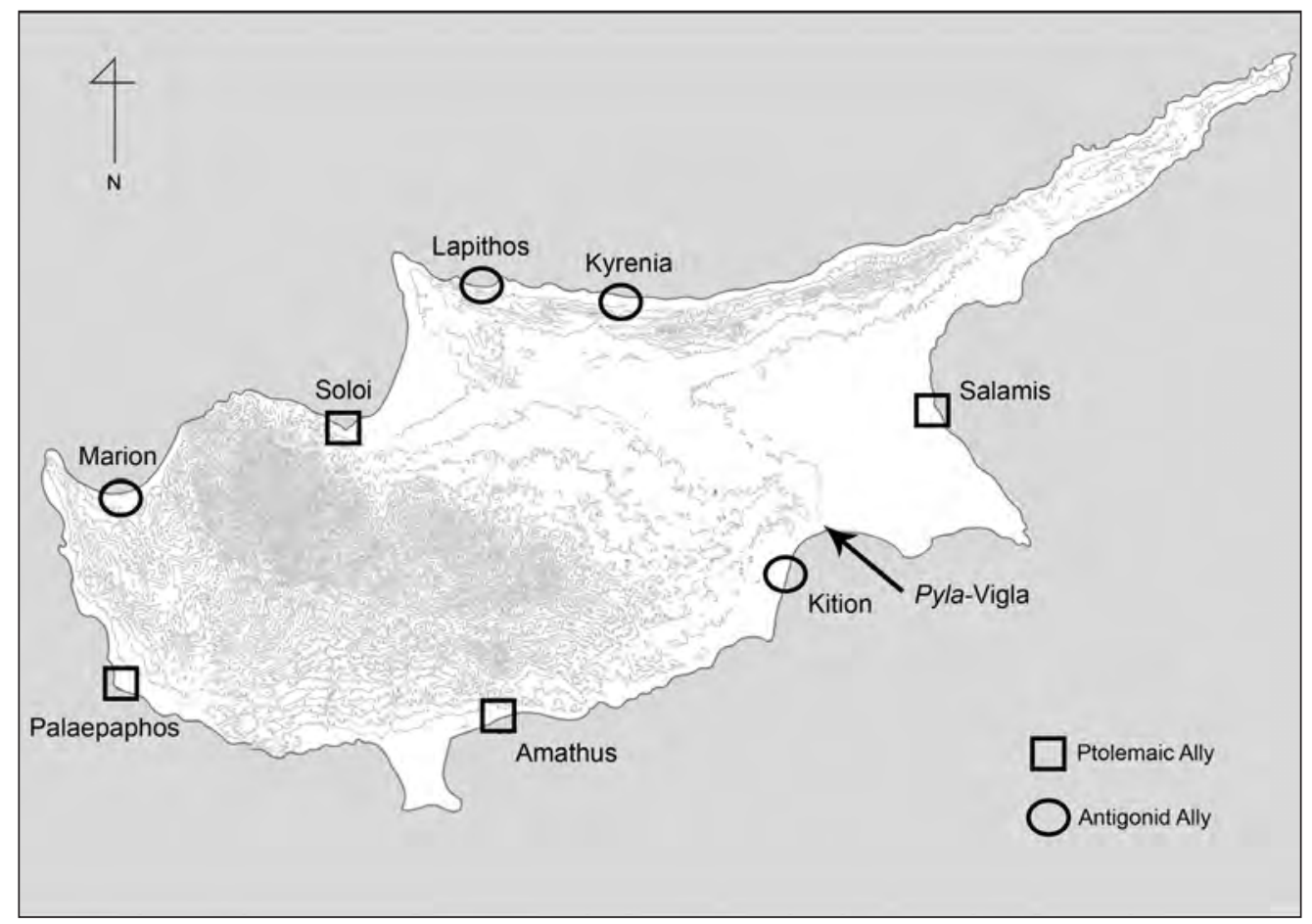

11. A map showing Diadochoi alliances with local Cypriot city-state kings (Drawing: B.R. Olson; ㄷ Pyla-Koutsopetria Archaeological Project).

century BC, was the most important mint on the island. ${ }^{21}$ The coins from Vigla were minted during this complex numismatic scene.

Ultimately, the question remains to what extent, if any, does the site of Vigla and its associated material remains reflect the imperial strategies of the Antigonids or Ptolemies? The historical evidence demonstrates a clear back and forth between the two Diadochoi beginning as early as $321 \mathrm{BC}$ with each group allying with specific city-states and the eventual takeover of the island by the Ptolemies in 294 BC (Table 3, Fig. 11). The geographic distribution of the respective alliances shows a pattern where the Antigonids favoured the north-west half of the island, while the Ptolemies bolstered their influence in the south-east. Notably, both sides have allied with one city in the other's sphere (Ptolemy at Soloi and Antigonus at Kition). The fortifications and associated material culture demonstrate that Vigla was a short-lived fortified military garrison, while the numismatic evidence, based on the presence of two issues and the minting realities of the early Hellenistic period in Cyprus outlined by Anne Destrooper-Georgiades and Paul Keen, provide a chronology for the construction, use, and abandonment of Vigla between 323-294 вс.22 This historical

\footnotetext{
21 Keen 2012: 74-80.

22 Keen 2012.
} 
Table 3. Diadochoi control of Cyprus

\begin{tabular}{|l|l|}
\hline \multicolumn{1}{|c|}{ Phase } & \multicolumn{1}{c|}{ Definition } \\
\hline $\begin{array}{l}\text { Dual Antigonid and Ptolemaic } \\
\text { Interests (321-316 BC) }\end{array}$ & $\begin{array}{l}\text { Joint interests in Cyprus solidified by Ptolemaic and Antigonid alliances } \\
\text { with various Cypriot kings (Ptolemy: Paphos, Amathus, Soloi, and Salamis; } \\
\text { Antigonus: Kition, Kyrenia, Lapithos, and Marion). }\end{array}$ \\
\hline Ptolemaic Phase 1 (316-306 BC) & $\begin{array}{l}\text { Begins with a Ptolemaic subjugation of Antigonid Cypriot allies and ends } \\
\text { with the Battle of Salamis. }\end{array}$ \\
\hline Antigonid Control (306-294 BC) & $\begin{array}{l}\text { Begins with the victory over Ptolemy at Salamis and ends with the reconquest } \\
\text { of Cyprus by Ptolemy. }\end{array}$ \\
\hline Ptolemaic Phase 2 (294-58 BC) & Begins with Ptolemaic reconquest and ends with the arrival of the Romans. \\
\hline
\end{tabular}

record provides two options: a Ptolemaic foundation dating to their first phase of control on the island between 316-306 BC or an Antigonid foundation dating to their only phase of singular control of the island between 306-294 BC (Table 3). A construction before 316 BC does not seem possible as the Diadochoi simply allied themselves with the existing city-state kings. Thus, there would have been little need for a Greek garrison occupying a fortified space between Kition and Salamis. A post 294 BC construction seems unlikely as well, given the absence of the standard assemblage of Ptolemaic material culture so ubiquitous at Ptolemaic sites near the island. Furthermore, the Ptolemies shifted their attention and capital from Salamis to the west side of the island at Paphos during the third century BC.

\section{CONCLUSIONS}

The construction of fortified garrisons outside of established urban spaces was an imperial practice of the Diadochoi to maintain control of newly subjugated lands. The features were multi-fold in that they provided a means of defending a valuable space against an invading rival and provided the means and setting to subjugate a previously autonomous local population. Vigla fits within this pattern logistically and chronologically. The short-term need for these spaces following $294 \mathrm{BC}$ is evident as there is no evidence of a continued Ptolemaic presence during the third through the first centuries BC. The need for fortified garrisons outside of civic spaces ceased once a singular imperial power controlled the entire island and there was little threat of invasions from rival successors. Following the third century, the imperial efforts of the Ptolemies shift to the western side of the island and there is little archaeological evidence of settlement at Vigla and its immediate environs following this. The Pyla region did rebound, however, and saw a steady increase in activity from the early Roman into the late Roman period that mirrored the expansion occurring on the rest of the island. This growth in settlement density and agricultural activity corresponded to the island, assuming a more prominent role in the economy of the Eastern Mediterranean during the early and late Roman eras. ${ }^{23}$ As Cyprus came under Roman political control, settlement in the Pyla region flourished along the harbour's coastline demonstrating both

\footnotetext{
23 Leonard 2005: 200.
} 
the focus on commercial exchange and a significantly decreased concern over security and safety. This expansion to the coast, however, was not matched by a corresponding expansion into the interior, which did not appear to benefit from the economic growth in the coastal zone. Interestingly, despite the sizeable settlement in the plain south and south-west of Vigla, there is no evidence of renewed settlement or use of the plateau.

The strong economic activity in the region came to an abrupt stop by the end of the seventh century AD when the area had been completely abandoned. This sudden end to a period of peaceful prosperity is seen at numerous coastal sites around the island, such as Maroni-Petrera, Kourion, and Paphos. ${ }^{24}$ While some scholars have attributed this decline in the seventh century AD to the Arab invasions, it is clear that other factors played a role. ${ }^{25}$ There is also little evidence for continued activity in the interior north of Pyla. ${ }^{26}$ The only site which continues to function after the seventh century decline seems to be the village of Pyla, to the north of Vigla, and this may reflect the movement of the people living in the coastal zone south of Vigla to a more protected inland community. The region never seems to have recovered, and Pyla is the only site to continue into the Medieval period and modern times. ${ }^{27}$

\section{References}

Balandier, C. 2002: La défense des territoires à Chypre de l'époque archaïque aux invasions arabes (VIII ${ }^{\mathrm{e}}$ s. av. n.è.-VII ${ }^{\mathrm{e}}$ s. de n.è.), DHA 28/1, 175-206

Balandier, C. 2007: Les ouvrages fortifiés et la défense territoriale de Chypre à la transition des périodes classique et hellénistique, [in:] Flourentzos, P. (Ed.), From Evagoras I to the Ptolemies. The Transition from the Classical to the Hellenistic Period in Cyprus. Proceedings of the International Conference, Nicosia, 29-30 November 2002, Nicosia, 145-159

Balandier, C. 2011a: La défense de Chypre et l'importance stratégique de l'île dans la politique lagide, [in:] Demetriou, A. (Ed.), Proceedings of the IVth International Cyprological Congress, Nicosia 29 April-3 May 2008, vol. 1, Nicosia, 367-376

Balandier, C. 2011b: La défense de la Transeuphratène occidentale par les Achéménides. Études des fortifications de Chypre et de Palestine cisjordanienne, Transeuphratène 40, 9-32

Caraher, W., Moore, R.S., Nakassis, D., Pettegrew, D.K. 2017: Pyla-Koutsopetria Archaeological Project: Recent Work at the Site of Pyla-Vikla, RDAC 2011-2012, 443-459

Caraher, W., Moore, R.S., Noller, J.S., Pettegrew, D.K. 2005: The Pyla-Koutsopetria Archaeological Project: First Preliminary Report (2003-2004 Seasons), RDAC 2005, 245-267

\footnotetext{
24 Manning et al. 2002: 78; Megaw 2007: xxv, 174-175.

25 Chrysos 1993: 10-14.

${ }^{26}$ Moore, Gregory 2012: 208.

${ }^{27}$ Caraher, Moore, Pettegrew 2014: 295-297.
} 
Caraher, W., Moore, R.S., Noller, J.S., Pettegrew, D.K. 2007: The Pyla-Koutsopetria Archaeological Project: Second Preliminary Report (2005-2006 Seasons), RDAC 2007, 293-306

Caraher, W., Moore, R.S., Pettegrew, D. 2008: Surveying Late Antique Cyprus, NEA (ASOR) 71/1-2, 82-89

Caraher, W., Moore, R.S., Pettegrew, D. 2014: Pyla-Koutsopetria I: Archaeological Survey of an Ancient Coastal Town, ASOR Archaeological Reports 21, Boston

Chrysos, E. 1993: Cyprus in Early Byzantine Times, [in:] Breyer, A.A.M., Georghallides, G.S. (Eds), 'The Sweet Land of Cyprus'. Papers Given at the Twenty-Fifth Jubilee Spring Symposium of Byzantine Studies, Birmingham, March 1991, Nicosia, 3-14

Clarke, G.W., Connor, P.J., Crewe, L., Frohlich, B., Jackson, H., Littleton, J., Nixon, C.E.V., O’Hea, M., Steele, D. 2002: Jebel Khalid on the Euphrates: Report on Excavations 1986-1996, vol. 1, MeditArch Supplement 5, Sydney

Destrooper-Georgiades, A. 2007: The Cypriote Coinage During the 4th Century B.C.: Unified or Chaotic Evolution in the Hellenistic Period?, [in:] Flourentzos, P. (Ed.), From Evagoras I to the Ptolemies. The Transition from the Classical to the Hellenistic Period in Cyprus. Proceedings of the International Conference, Nicosia, 29-30 November 2002, Nicosia, 265-282

Foraboschi, D. 1971: Onomasticon Alterum Papyrologicum: Supplemento al Namenbuch di F. Preisigke, Milano

Fraser, P.M., Matthews, E. 1987: A Lexicon of Greek Personal Names, vol. 1: Aegean Islands, Cyprus, Cyrenaica, Oxford

Gordon, J.M. 2012: Between Alexandria and Rome: A Postcolonial Archaeology of Cultural Identity in Hellenistic and Roman Cyprus, unpublished PhD thesis, University of Cincinnati, Cincinnati

Hadjicosti, M., Caraher, W., Moore, R.S., Pettegrew, D. forthcoming: Pyla-Koutsopetria II: Archaeological Survey of an Ancient Coastal Town, ASOR Archaeological Reports, Boston

Kantirea, M., Summa, D. (Eds) 2020: Inscriptiones Graecae XV. Inscriptiones Cypri Insulae. Pars II. Inscriptiones Cypri Alphabeticae. Fasciculus I. Inscriptiones Cypri Orientalis: Citium, Pyla, Golgi, Tremithus, Idalium, Tamassus, Kafizin, Ledra, Berlin

Keen, P.W. 2012: Land of Experiment: The Ptolemies and the Development of Hellenistic Cyprus, 312-58 BC, unpublished PhD thesis, The University of Chicago, Chicago

Landvatter, T., Olson, B.R., Reese D.S., Stephens, J., Moore, R.S. 2018: Pyla-Koutsopetria Archaeological Project: Excavations at Pyla-Vigla in 2018, JHPMC 3, 179-186

Leonard, J.R. 2005: Roman Cyprus: Harbors, Hinterlands, and “Hidden Powers”, unpublished PhD thesis, The University of Buffalo, Buffalo

Manning, S.W., Manning, A., Tomber, R., Sewell, D.A., Monks, S.J., Ponting, M.J., Ribeiro, E.C. 2002: The Late Roman Church at Maroni Petrera: Survey and Salvage Excavations 1990-1997, and Other Traces of Roman Remains in the Lower Maroni Valley, Cyprus, Nicosia 
Megaw, A.H.S. 2007: Kourion: Excavations in the Episcopal Precinct, DOS 38, Washington, D.C.

Moore, R.S., Gregory, T.E. 2012: Athienou Archaeological Project Survey Pottery, [in:] Toumazou, M., Kardulias, P.N., Counts D.B. (Eds), Crossroads and Boundaries: The Archaeology of Past and Present in the Malloura Valley, Cyprus, AASOR 65, Boston, 203-214

Moore, R.S., Olson, B.R. 2014: Catalogue of Finds, [in:] Caraher, W., Moore, R.S., Pettegrew, D., Pyla-Koutsopetria I: Archaeological Survey of an Ancient Coastal Town, ASOR Archaeological Reports 21, Boston, 69-150

Nicolaou, I. 1977: Inscriptiones Cypriae Alphabeticae XVI, RDAC 1976, 209-221

Nicolaou, I. 1979: Inscriptiones Cypriae Alphabeticae XVIII, RDAC 1978, 344-351

Nicolaou, I. 1980: Inscriptiones Cypriae Alphabeticae XIX, RDAC 1979, 260-266

Olson, B.R. 2014: A Contextual and Epigraphic Analysis of the Inscribed Glandes (Sling Bullets), [in:] Caraher, W., Moore, R.S., Pettegrew, D., Pyla-Koutsopetria I: Archaeological Survey of an Ancient Coastal Town, ASOR Archaeological Reports 21, Boston, 155-163

Olson, B.R., Caraher, W., Pettegrew, D.K., Moore, R.S. 2013: The Pyla-Koutsopetria Archaeological Project: A Preliminary Report on Excavations at Pyla-Vigla, A Fortified Settlement Dating to the Hellenistic Era, JAEI 5/3, 74-82

Olson, B.R., Najbjerg. T. 2017: A Deposit of Scythian Type Arrowheads from Polis Chrysochous (ancient Arsinoe), RDAC 2011-2012, 639-656

Olson, B.R., Najbjerg, T., Moore, R.S. 2018: Chasing Arsinoe (Polis Chrysochous, Cyprus): A Sealed Early Hellenistic Cistern and Its Ceramic Assemblage, JHPMC 3, 9-29

Papantoniou, G. 2012: Religion and Social Transformation in Cyprus: From the Cypriot Basileis to the Hellenistic Strategos, Mnemosyne-Suppl. 347, Leiden-Boston

Preisigke, F. 1967: Namenbuch, Amsterdam

Stephens, J., Olson, B.R., Landvatter, T., Moore, R.S. 2019: Pyla-Koutsopetria Archaeological Project: Excavations at Pyla-Vigla in 2019, JHPMC 4, 28-43 


\section{ÉTUDES et TRAVAUX XXXIV / 2021}
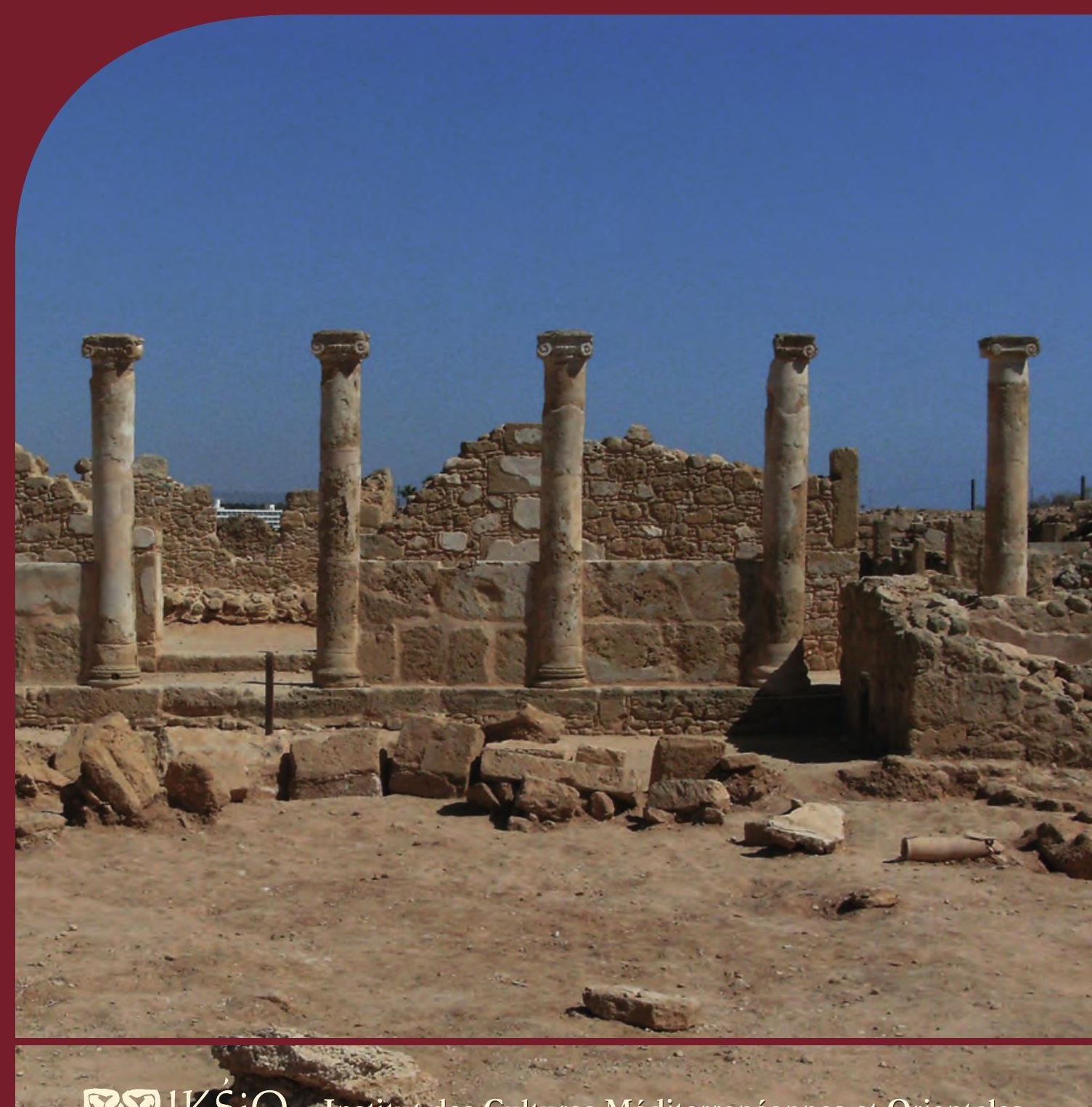

W $92 \mathrm{HKSiO}$ Institut des Cultures Méditerranéennes et Orientales

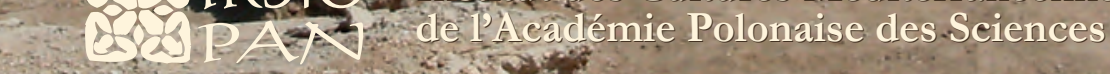

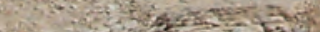

Q 
COMITÉ DE RÉDACTION SCIENTIFIQUE

Maciej Makowski - rédacteur en chef

Jadwiga Iwaszczuk - rédacteur

Katarzyna Kapiec - secrétaire de la rédaction

Henryk Meyza - rédacteur thématique du volume

CONSEIL SCIENTIFIQUE DU JOURNAL

M. Kobusiewicz (IAE PAN, Warszawa)

E. Laskowska-Kusztal (IMOC PAS, Warszawa)

D. Michaelides (University of Cyprus, Nicosia)

J.Ch. Moretti (IRAA-MOM, Université de Lyon 2/CNRS)

D. Raue (Ägyptisches Museum der Universität Leipzig)

P. Reynolds (ICREA, España)

D. Welsby (British Museum, London)

COMITÉ SCIENTIFIQUE DE LECTURE

la liste des membres du comité est accessible en ligne sur

http://www.etudesettravaux.iksiopan.pl

RÉDACTION TECHNIQUE

Marta Kaczanowicz

REVUE DES TEXTES EN ANGLAIS

Jo Harper 
ÉTUDES et TRAVAUX XXXIV 
INSTYTUT KULTUR ŚRÓDZIEMNOMORSKICH I ORIENTALNYCH POLSKIEJ AKADEMII NAUK

\title{
STUDIA i PRACE
}

\section{XXXIV}

\author{
GoIKSiO \\ QSO PAN \\ WARSZAWA \\ 2021
}


INSTITUT DES CULTURES MÉDITERRANÉENNES ET ORIENTALES DE L’ACADÉMIE POLONAISE DES SCIENCES

\section{ÉTUDES et TRAVAUX}

XXXIV

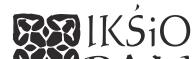

EOSPAN

VARSOVIE

2021 
Publication scientifique financée dans le cadre du programme du Ministre de la Science et de l’Éducation Supérieure

« Programme National de Développement de l’Humanistique » pour les années 2016-2021 (projet no 3bH 150099 83)

\title{
(1) NARODOWY PROGRAM ROZWOJU HUMANISTYKI
}

\author{
Copyright $(C)$ \\ Instytut Kultur Śródziemnomorskich i Orientalnych PAN \\ et les Auteurs \\ Warszawa 2021
}

ISSN 2084-6762

(jusqu'en 2011 : 0079-3566)

e-ISSN 2449-9579
Version première en papier, imprimée en Pologne - 150 copies
Version électronique accessible sur
http://www.etudesettravaux.iksiopan.pl

Édition: Polskie Towarzystwo Historyczne et Wydawnictwo Neriton, Warszawa

Conception générale de la couverture : J. Iwaszczuk

Photographie de couverture : Phot. A. Brzozowska-Jawornicka

(Le portique ionique est, péristyle de la Maison « hellénistique », Nea Paphos) 


\section{Table des matières}

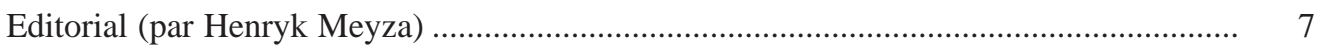

Marta BaJTLER

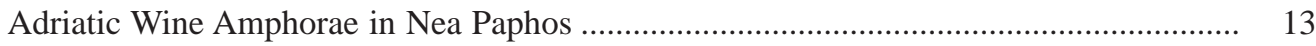

Claire Balandier, Jolanta MlynarczyK

The Temple and Its Surroundings on Fabrika Hill, Paphos: Preliminary Results

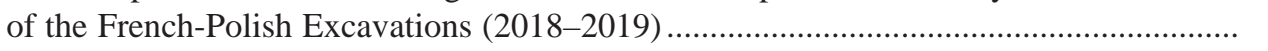

Grażyna BĄKowska-Czerner, Rafal CzERner

The Shell Motif in the Culture and Architecture of the Ancient Town of Marina el-Alamein in Egyp

AleKsandra BrzozowsKa-JaWornicKa

'Hellenistic' House in Nea Paphos, Cyprus - A First Summary of Its Architecture.

AleKsandra BrzozowsKa-JaWORnicKA, AnNa KuBICKA-SowińsKa

In Search of the Module in the Architectural Design of the 'Hellenistic'

House in Nea Paphos, Cyprus

RoKsana HaJduga

Kushite Stamp Impressions from Selib 2, Sudan

ERSIN HusSEIN

Mapping Metal Rich Roman Cyprus: The Case for Object-Centred Approaches

BARBARA LICHOCKA

Villa of Theseus at Nea Paphos (Cyprus). Fourth-Early Fifth Century Numismatic

Evidence for Architectural Transformations and Seismic Events

VASiliki Lysandrou, Demetrios Michaelides

Wall Paintings in Ancient Cyprus: The Hellenistic and Roman Tombs of Paphos

and Its Region

ADAM ŁAJTAR

A Weight of Seleucia in Pieria in Nea Paphos

Diana MroczeK

Ancient Portrait Busts of Marcus Aurelius in the National Museum in Poznań 
Brandon R. Olson, R. Scott Moore, Thomas Landvatter, Justin Stephens

Pyla-Vigla: A Case Study Assessing the Imperial Strategies of the Hellenistic

Diadochoi in Cyprus

Patrizio Pensabene, Eleonora Gasparini

Colonnaded Hall in Kourion: How the Oecus Corinthius Was Interpreted in the Roman

Houses of Cyprus

Monika Rekowska, Demetrios Michaelides, Skevi Christodoulou, JAKUB KANISZEWSKI

Adopting Roman Habits - The Baths in the House of Orpheus in Nea Paphos

as a 'Troublesome' Case Study?

MARCIN M. ROMANIUK

Terracotta Pipelines at Maloutena: Remarks on the Water System in the

Residential District of Ancient Nea Paphos, Cyprus

363

ABRÉVIATIONS

407 